\title{
A MORPHOMETRIC AND MOLECULAR STUDY OF THE GENUS PSEUDOPODISMA (ORTHOPTERA: ACRIDIDAE)
}

\author{
Máté Kisfali ${ }^{1}$, Péter Sólymos², Antal Nagy ${ }^{3}$, István A. Rácz ${ }^{1}$ \\ Orsolya Horváth ${ }^{4}$ and Gábor SRAmkó 4,5
}

\begin{abstract}
${ }^{1}$ Department of Evolutionary Zoology and Human Biology, University of Debrecen, H-4010 Debrecen, P.O. Box 3, Hungary; E-mails: mkisfali@gmail.com; racz.istvan@science.unideb.hu

${ }^{2}$ Alberta Biodiversity Monitoring Institute and Department of Biological Sciences CW 405, Biological Sciences Bldg., University of Alberta, Edmonton, Alberta, T6G 2E9, Canada E-mail: solymos@ualberta.com

${ }^{3}$ Institute of Plant Protection, University of Debrecen

H-4032 Debrecen, Böszörményi út 138, Hungary; E-mail: nagyanti@agr.unideb.hu ${ }^{4}$ Department of Botany, University of Debrecen, H-4010 Debrecen, Egyetem tér 1, Hungary E-mails: horsolya@gmail.com; sramko.gabor@science.unideb.hu ${ }^{5}$ MTA-DE "Lendület" Evolutionary Phylogenomics Research Group H-4010 Debrecen, Egyetem tér 1, Hungary
\end{abstract}

The specific status of three described taxa belonging to the genus Pseudopodisma (P. fieberi, $P$. transilvanica, $P$. nagyi) is based on a single character, because the original descriptions separate the species solely on the basis of genital structure of the males, and the three species are seemingly indistinguishable based on external morphology. To test this taxonomic separation we conducted morphometric and molecular investigations in the genus. Males were a priori identified by the original descriptions of the taxa, and from 18 external morphometric characters collected, the six most eligible characters of males and females were selected for linear discriminant analysis. The linear discriminant based classification agreed for $35(85.3 \%)$ male and $30(88.2 \%)$ female specimens out of the 41 a priori identified males and 34 females. Besides morphometrics, we sequenced the cytochrome $b$ gene with newly devised primers in all species plus two outgroups. The phylogenetic analysis of resulting sequences indicated a strong species-delimitation within the genus Pseudopodisma (i.e., multiple individuals of the a priori species formed monophyletic clades). Thus, taking the morphometric and molecular results into consideration, we conclude the validation of specific status of Pseudopodisma fieberi, P. nagyi and P. transilvanica within the genus.

Key words: $\mathrm{CytB}$, mitochondrial primers, grasshopper systematics, linear discriminant analysis, multivariate morphology.

\section{INTRODUCTION}

The genus Pseudopodisma (Orthoptera: Acrididae) includes three species. Pseudopodisma fieberi (Scudder, 1897) is the nominal species of the genus (Mistshenko 1947). Scudder (1897) originally described this species from "Carniola" (today Slovenia), but also reported from Serbia and Transylvania. Galvagni and Fontana (1991) described the same species again as Pseudopodisma disconzii (junior synonym) from Italy. The original holotype of $P$. fieberi 
was lost, therefore Harz designated a neotype from Cluj-Napoca (Romania) in 1957 (HARz 1957). This incorrect neotypification was corrected by GaLvaGNI and Fontana (1993), who appointed a new neotype from Slovenia, which corresponds to the original type locality (Fig. 1).

At the same time, Galvagni and Fontana (1993) also described P. transilvanica based on the individuals collected near Cluj-Napoca (West Romania) (Fig. 1). P. transilvanica was separated from P. fieberi based on morphology of male genitalia. Later, $P$. transilvanica was also found in Slovakia (KočÁreK et al. 1999), and other parts of Romania.

As part of their taxonomic revision, Galvagni and Fontana (1996) described P. nagyi from Hungary (type locality: peak "Galya-teto"” in the Mátra

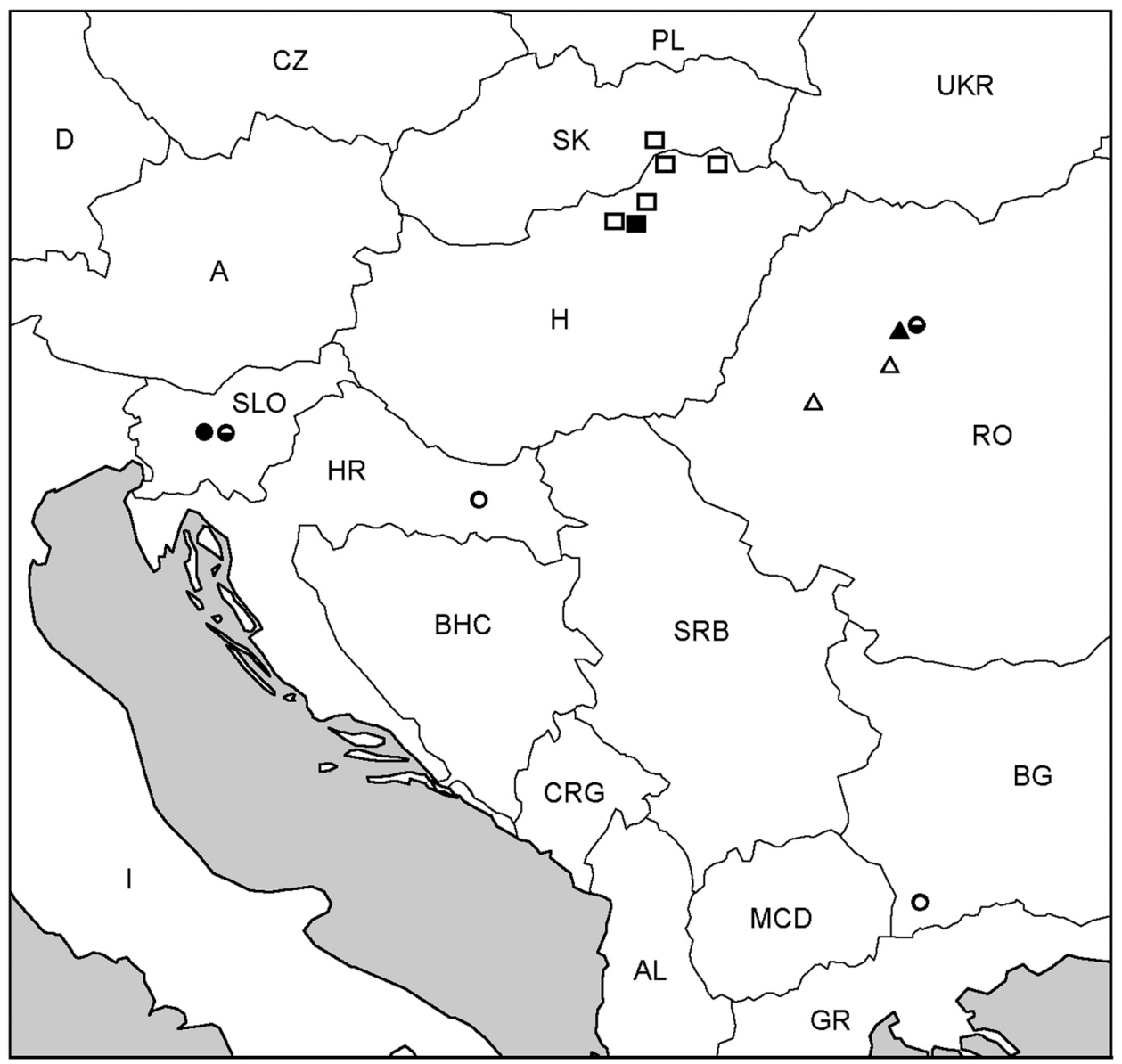

Fig. 1. Sampling sites, holotype and neotype localities of the studied Pseudopodisma species. Pseudopodisma fieberi: circle, P. nagyi: square, P. transilvanica: triangle; filled symbols: holotype, half-filled symbols: neotype, empty symbols: sampling sites for this study 
Mts) (Fig. 1), and it was also reported from Slovakia (KočÁReK et al. 2005). P. nagyi does not occur in Czech Republic (HoLuša et al. 2013), so the northern border of the distribution area of the genus is in Slovakia. The differential diagnosis of $P$. nagyi was also based on the morphology of male genitalia. The females of all three species are reported to be undistinguishable (GALVAGNI \& FontANA 1996).

Beyond these species descriptions only two papers provided some phylogenetic data on the genus Pseudopodisma. Litzenberger and Chapco (2001) mentioned $P$. nagyi in their study on the phylogenetic relationships and origin of the North American subfamily Melanoplinae (Orthoptera: Acrididae). They used $P$. nagyi as a representative species of the Pseudopodisma genus in their analysis. ChintauAn-Marquier et al. (2013) analyzed the evolutionary history of the Eurasian and European Podismini including only Pseudopodisma transilvanica out of the three Pseudopodisma species. The geographic distribution of the three Pseudopodisma species is little known and only sporadic records are available in the literature (e.g., Kiss 1961, NAGY et al. 2005). In Hungary, both habitat preference and geographic distribution of $P$. nagyi are well studied (Nagy \& Rácz 2007, Nagy et al. 2007, Nagy et al. 2010). In Romania, the checklist of orthopterans (Iongu et al. 2008) mentions P. fieberi and P. transilvanica from the same region, whereas Hoffmann (2009) reports the third species, $P$. nagyi, from Zarand Mts (SW Romania).

Male genitalia are thought to be extremely successful in species-delimitation in certain insect groups (e.g., Mutanen \& Pretorius 2007, Ilango 2011, CorrêA et al. 2012, TótH \& VARGA 2012) including grasshoppers (López et al. 2007). However, the geographic distribution - including the supposed sympatric occurrences of different species in Romania - together with the weak morphological differentiation among the species question their differentiation at the species level argues for a synonymization under $P$. fieberi. It is noteworthy that, unlike other orthopteran groups whose taxonomy is intensively studied based on song patterns (e.g., OrCi et al. 2010), this genus cannot be studied using these means as they do not stridulate. Therefore, in the current paper we examine the morphometric and molecular differentiation in the species of the Pseudopodisma genus based on external morphology and cytochrome $b(\mathrm{CytB})$ gene sequences of specimens collected from various localities within the distribution range of the genus.

\section{MATERIAL AND METHODS}

Samples - 41 males and 34 females of the three species were measured (Table 1). The $a$ priori species identification was based on the morphology of male genital structure as described by Galvagni and Fontana (1996). We assumed that the males and females from same locality belong to the same species. A subset of the above specimens (stored in 
$80 \mathrm{~V} / \mathrm{V} \%$ ethanol) was used in molecular characterization (Table 1). Because only relatively recent samples were suitable for PCR-amplification of the selected mitochondrial region, some samples were omitted from the molecular work. Altogether, we used six samples of the three species of Pseudopodisma, and one sample of Odontopodisma rubripes (RAmme, 1931) as closely related outgroup in the molecular work (Table 1).

Measurements - Eighteen morphometric characters were used in this study (Fig. 2): body length (BL), eyes distance (ED), fore tibia length (FTL), head length (HL), head width (HW), mesosternum lobe length (MLL), mesosternum lobe width (MLW), pronotum length (PL), pronotum width (PW), pronotum lateral side length (PLL), pronotum lateral side width (PLW), sternum length (SL), sternum width (SW), third femur length (TFL), third femur width (TFW), third tibia length (TTL), tegmen length (WL), tegmen width (WW). A Motic SMZ-168 stereomicroscope was used for all morphometric measurements. The specimens used in this study were preserved separately in $80 \mathrm{~V} / \mathrm{V} \%$ ethanol, and are deposited in the Entomological Collection at Department of Evolutionary Zoology and Human Biology, University of Debrecen, Hungary.

Morphometric data analysis - We performed a stepwise forward variable selection (Hocking 1976) using the Wilk's $\lambda$ criterion separately for both genders. Wilk's $\lambda$ is a generalization of the F-distribution and is a statistical test used in multivariate analysis of variance to show whether there are differences between the means of identified groups of subjects on a combination of dependent variables (EveritT \& DUNn 2001). The initial model

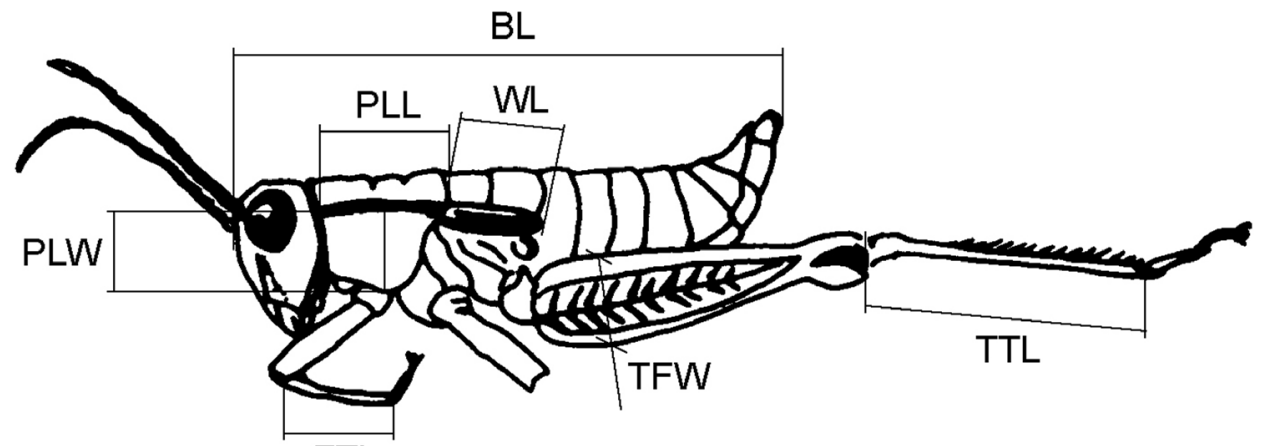

FTL
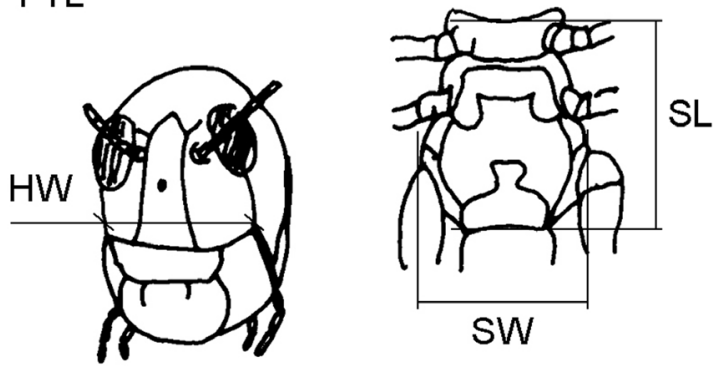

Fig. 2. Location of ten measured variables out of the 18 examined on the Pseudopodisma specimens. $\mathrm{BL}=$ body length, FTL = fore tibia length, $\mathrm{HW}=$ head width, PLL = pronotum lateral side length, PLW = pronotum lateral side width, SL = sternum length, SW = sternum width, TFW = third femur width, TTL = third tibia length, $\mathrm{WL}=$ tegmen length (Original drawing by HARz 1957) 


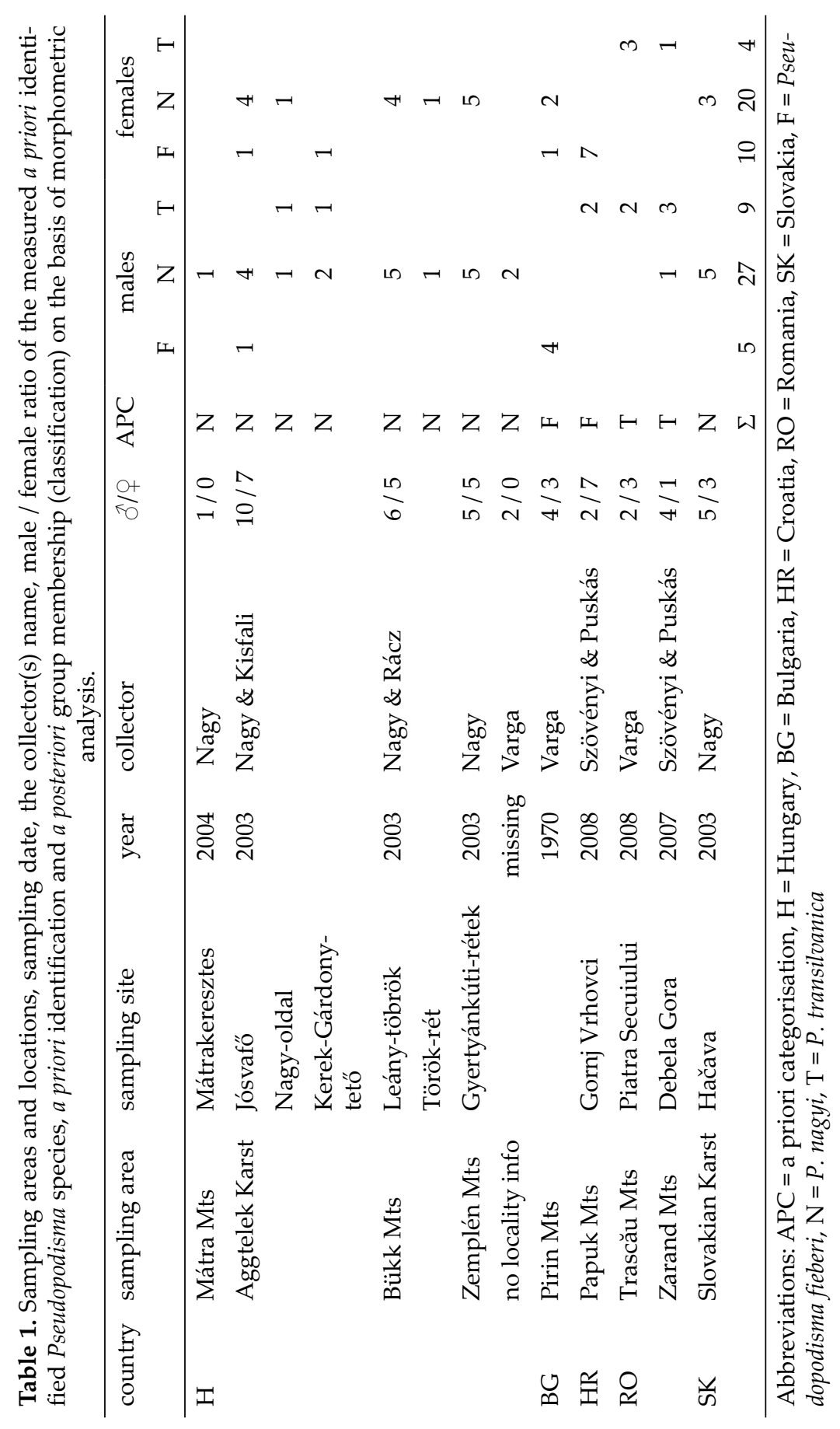


was defined starting with the variables that provided the best separation between groups. The model was then extended considering further variables depending on the Wilk's $\lambda$ criterion: select the one which minimizes the Wilk's $\lambda$ of the model including the variable if its $p$-value still shows statistical significance (MARDIA et al. 1979). This variable selection was performed by the 'klaR' package (Weins et al. 2005) of the R software (R Core DevelopMENT TEAm 2009).

This selection procedure resulted in a set of variables that were further analyzed by linear discriminant analysis (LDA; FISHER 1936). We used pre-defined group membership (species based on identification and location, as given in Table 1) to find linear combinations of the original variables that has a maximal ratio of separation of the class means to the within-class variance (Venables \& Ripley 2002). For three groups (and more than two variables), the number of linear discriminants that can be calculated is two. Resulting eigenvalues are the proportions of the variance between classes explained by the linear discriminants. LDA was performed by the MASS package (VenAbles \& Ripley 2002) of the R software (R Core Development Team 2009).

Molecular characterization - DNA was extracted by homogenizing the third femur of ethanol-preserved specimens in $800 \mu$ l extraction buffer described by GILBERT et al. (2007). The samples were incubated for $24 \mathrm{~h}$ at $56^{\circ} \mathrm{C}$ with gentle agitation and then centrifuged at $14000 \mathrm{rpm}$ for $1 \mathrm{~min}$. The supernatant was washed twice with an equal volume of chloroform-isoamyl alcohol (24:1) to remove proteins. The DNA was precipitated by adding the mixture of $80 \mu \mathrm{l}$ ammonium acetate $(7.5 \mathrm{M})$ and an equal volume of ice-cold isopropanol and storing the samples at $-20^{\circ} \mathrm{C}$ for $4 \mathrm{~h}$. The DNA was pelleted by centrifugation at 14000 rpm for 10 minutes at $4^{\circ} \mathrm{C}$. After centrifugation, the supernatant was discarded and the DNA pellet was washed twice with $70 \mathrm{~V} / \mathrm{V} \%$ ice-cold ethanol. The pellet was air dried for $1 \mathrm{~h}$ at room temperature, and was re-dissolved in $50 \mu$ lelution buffer $(10 \mathrm{mM}$ Tris $\mathrm{HCl}, \mathrm{pH}$ 8.0 and 0.5 mM EDTA, pH 9.0).

The cytochrome $b$ gene $(\mathrm{Cy} t \mathrm{~B})$ of the mitochondrion, which can provide an alternative to the widely used cytochrome $c$ oxidase I (COI) for recently diverged taxa (НевеRт $e t$ al. 2003) because it has comparable resolution at terminal branches of insect phylogenetic trees (Simmons \& WeLLer 2001), offers an adequate tool to test the putative separation of Pseudopodisma species. Although Litzenberger and Chapco (2001) provided primers for the amplification of the $C y t B$ region in grasshoppers, they performed poorly in our amplification experiments. To overcome this, we devised new primers to specifically amplify the $\mathrm{Cyt} \mathrm{B}$ region by determining conservative regions in two closely related species (Ognevia, Prumna) with complete mitochondrial genome available (GenBank identifiers: EU914848, NC_013835, respectively). The following primers were devised: "CytB-SaskaIFw" (5' CCG TTC ATG CTA ATG GAG C - 3') as forward, and "CytB-SaskaRv" (5' - GGA CTT TAC CTC GTT TTC G - 3') as reverse primer. With these primers, we were able to specifically amplify a 1047 bp long region located between bp 10686-11718 (as compared to Ognevia-EU914848) that covers 852 bp of the $3^{\prime}$ end of the CytB region and small portion of the $5^{\prime}$ end of the ND1 gene in the following PCR-conditions. The reaction mixture contained: $0.2 \mathrm{mM}$ dNTP, $2 \mathrm{mM} \mathrm{Mg}, 1 \mathrm{mg} / \mathrm{ml}$ BSA, $0.2 \mu \mathrm{M}$ of each primer, $0.02 \mathrm{U}$ Phusion Hot Start II High-Fidelity DNA Polymerase (Thermo Fisher Scientific Ltd.) and $2 \times$ of the corresponding reaction buffer (Phusion HF). The amplification was performed in a Veriti 9600 thermal cycler (Applied Biosystem) programmed for: initial denaturation at $98^{\circ} \mathrm{C}$ for $45 \mathrm{sec}$, followed by 35 cycles of denaturation at $98^{\circ} \mathrm{C}$ for $15 \mathrm{sec}$, annealing at $58^{\circ} \mathrm{C}$ for 30 sec, extension at $72^{\circ} \mathrm{C}$ for $1 \mathrm{~min}$, and a final extension at $72^{\circ} \mathrm{C}$ for $7 \mathrm{~min}$. The amplification success was checked on $1 \%$ agarose gel stained with ethidium-bromide. Successfully 
amplified products were submitted to be sequenced from both directions by commercially available service provider (Macrogen Inc., South Korea) using the original amplification primers as sequencing primers.

Molecular phylogenetic analysis - The forward and reverse sequences of the same sample were manually checked for errors, then continuous reads ("contigs") were made by hand using the software Chromas Lite v.2.1 (Technelysium Pty Ltd.). Sequences were aligned manually in BioEdit v.7.1.3 (Hall 1999). Phylogenetic analysis of the sequences employed an exhaustive search under the maximum parsimony criterion as implemented in PAUP v.4.0b*10 (Swofford 2003). The number of sequences allowed an exhaustive search to be conducted, thus we performed this analysis, which examine all possible trees in the virtual tree-space. The overlapping part of sequence of Ognevia (EU914848) was used as distantly, while that of Odontopodisma rubripes (RAmme, 1931) as closely related outgroup. With the inclusion of two, differently related outgroup taxa we also tested the cohesiveness of the genus Pseudopodisma. The search treated every character as unordered and unweighted, gaps as missing. The statistical robustness of the resulted topology was checked in a bootstrap test with 1000 pseudo-replications.

\section{RESULTS}

\section{Morphometrics}

For males, six variables were selected (BL, FTL, PLW, SL, SW, WL) (Fig. 2 ) out of the 18 measured variables based on Wilk's $\lambda$ values. The first discriminant (LD1) separated $P$. nagyi from $P$. transilvanica and P. fieberi (Fig. 3). Standardized coefficients of LD1 were the highest for predictors SL, SW and PLW (Table 2). This indicates that sternum length, sternum width and the pronotum lateral side width are suitable for discriminate between P.nagyi and the other two species, $P$. transilvanica and $P$. fieberi. The second discriminant (LD2) led to a separation between $P$. transilvanica and $P$. fieberi (Fig. 3). Standardized
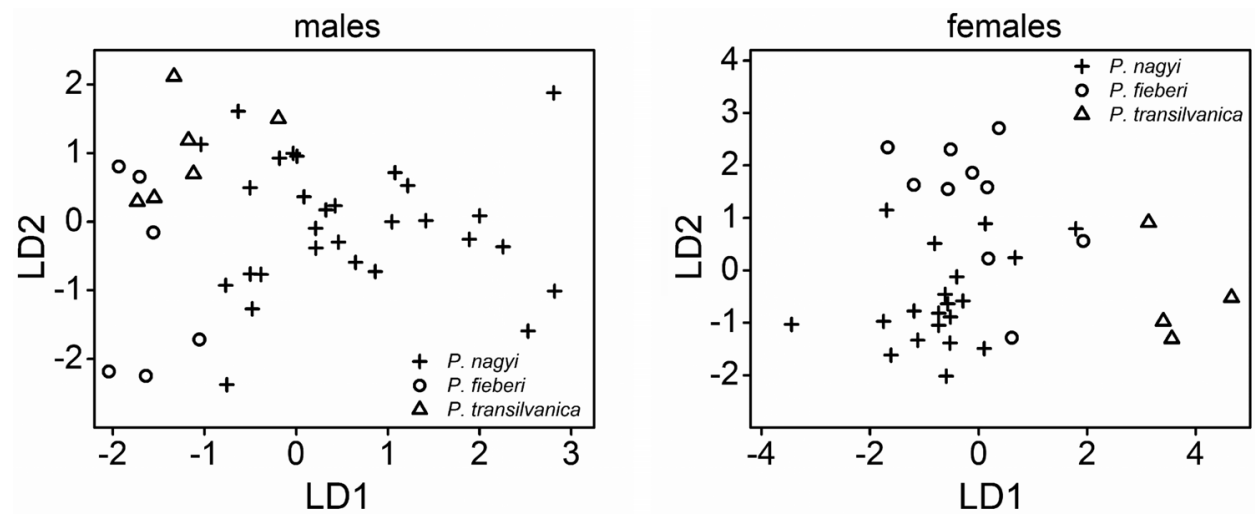

Fig. 3. Linear discriminant analysis results for males (left) and females (right). Each point represents an individual 
Table 2. Six most important discriminating characters between groups, mean and standard deviation $( \pm S D)(\mathrm{mm})$. LD1 and LD2 shows standardized coefficient values for each character, larger absolute values mean higher discriminating ability.

\begin{tabular}{lcccccc}
\hline Sex & Characters & P. fieberi & P. nagyi & P. transilvanica & LD1 & LD2 \\
\hline Male & WL & $3.62( \pm 0.37)$ & $3.87( \pm 0.37)$ & $3.39( \pm 0.39)$ & 0.81 & -1.80 \\
& FTL & $3.41( \pm 0.25)$ & $3.58( \pm 0.20)$ & $3.59( \pm 0.06)$ & 0.65 & 5.22 \\
& SL & $4.97( \pm 0.34)$ & $4.90( \pm 0.25)$ & $4.91( \pm 0.26)$ & -3.70 & -1.85 \\
& SW & $3.53( \pm 0.47)$ & $3.96( \pm 0.38)$ & $3.74( \pm 0.22)$ & 2.29 & 0.67 \\
& PLW & $2.18( \pm 0.19)$ & $2.52( \pm 0.46)$ & $2.30( \pm 0.22)$ & 1.41 & 0.12 \\
& BL & $18.97( \pm 1.59)$ & $19.74( \pm 2.17)$ & $17.84( \pm 0.67)$ & 0.28 & -0.18 \\
& PLW & $2.69( \pm 0.20)$ & $2.99( \pm 0.15)$ & $2.85( \pm 0.24)$ & -3.92 & -2.90 \\
& WL & $4.49( \pm 0.46)$ & $4.93( \pm 0.50)$ & $4.06( \pm 0.46)$ & -2.46 & -0.12 \\
& TTL & $10.02( \pm 0.46)$ & $10.36( \pm 0.56)$ & $10.90( \pm 0.48)$ & 1.42 & -0.29 \\
& TFW & $2.89( \pm 0.29)$ & $3.06( \pm 0.17)$ & $2.90( \pm 0.34)$ & -4.05 & 0.27 \\
& PLL & $4.35( \pm 0.36)$ & $4.78( \pm 0.25)$ & $4.83( \pm 0.28)$ & 3.04 & -1.06 \\
& HW & $2.60( \pm 0.35)$ & $2.93( \pm 0.27)$ & $3.03( \pm 0.05)$ & 1.73 & -1.51 \\
\hline
\end{tabular}

Abbreviations: BL: body length, FTL: fore tibia length, HW: head width, PLL: pronotum lateral side length, PLW: pronotum lateral side width, SL: sternum length, SW: sternum width, TFW: third femur width, TTL: third tibia length, WL: tegmen length; LD: linear discriminant function axes

coefficients of LD2 were highest for predictors FTL, SL and WL (Table 2). This indicates that fore tibia length, sternum length and the tegmen length are suitable variables to discriminate between $P$. transilvanica and $P$. fieberi. For males, LD1 accounted for $77.27 \%$, while LD2 accounted for $22.73 \%$ of the variance between classes, singular values (giving the ratio of the between- and withingroup standard deviations on the linear discriminant variables) were 4.17 and 2.26 for the two axes, respectively.

For females, the same six variables were selected (HW, PLL, PLW, TFW, TTL, WL) (Fig. 2) out of the 18 measured variables based on Wilk's $\lambda$ values. The first discriminant (LD1) led to a separation between $P$. transilvanica and the other two species, P. nagyi and P. fieberi (Fig. 3). Standardized coefficients of LD1 were highest for predictors TFW, PLW, PLL and WL (Table 2). Consequently the third femur width, pronotum lateral side width, pronotum lateral side length and the tegmen length were appropriate variables to discriminate between $P$. transilvanica and the other two species. The second discriminant (LD2) separated P. nagyi and P. fieberi (Fig. 3). Standardized coefficients of LD2 were the highest for predictors PLW and HW (Table 2). This point out that pronotum lateral side width and head width had highest discriminatory power to distinguish $P$. nagyi and $P$. fieberi. For females, LD1 accounted for 
$71.31 \%$, while LD2 accounted for $28.68 \%$ of the variance between classes, singular values were 5.66 and 3.59 for the two axes, respectively.

Out of the six males, a priori identified as $P$. fieberi, four specimens were correctly classified; the remaining two Croatian specimens were classified together with the $P$. transilvanica group. The proportion of correctly identified specimens was $66.6 \%$. Out of the 29 males, a priori identified as P. nagyi, 26 specimens were correctly classified; two specimens from the Aggtelek Karst (Hungary) were classified with the $P$. transilvanica and one with the $P$. fieberi group. The accuracy of classification was $89.6 \%$. Out of the six males, a priori identified as $P$. transilvanica, five specimens were correctly classified; the remaining sample from Zarandi Mts (Romania) was classified together with the P. nagyi group. The accuracy of classification was $83.3 \%$ (Table 1 ).

Out of the ten females, a priori identified as P. fieberi, eight specimens were correctly classified; the remaining two samples from Bulgaria were assigned to $P$. nagyi group. The proportion of correctly classified specimens was $80 \%$. Out of the 20 P. nagyi females, only two specimens from the Aggtelek Karst were classified together with the $P$. fieberi group. The proportion of correctly classified specimens was $90 \%$. Out of the four females, a priori identified as $P$. transilvanica, all four specimens were correctly classified, the proportion of correctly classified specimens was 100\% (Table 1).

Out of the 41 a priori identified males, 35 specimens were correctly classified (85.3\%), out of the 34 a priori identified females, 30 specimens were correctly assigned to its group $(88.2 \%)$ (Table 1$)$.

\section{Molecular phylogenetic characterization}

The newly devised primers produced unambiguous reads from both (forward and reverse) directions and allowed the concatenation of a $1047 \mathrm{bp}$ long part of the CytB region in Pseudopodisma, $1043 \mathrm{bp}$ in Odontopodisma. A final alignment of all sequences had a total number of aligned positions of 1054, out of which 183 were variable, and 59 parsimony-informative. For the Pseudopodisma samples, the above characteristics are 43 and 15, respectively. The exhaustive search under maximum parsimony criterion resulted in a single most-parsimonious phylogenetic tree (Fig. 4) with consistency index (CI) of 0.9563 , homoplasy index (HI) of 0.0437 , and retention index (RI) of 0.8929 . The bootstrap procedure strongly supported (i.e., bootstrap above 85\%) all but one branch, which - the one separating two Hungarian samples from the third - received weak bootstrap support (62\%).

The $1047 \mathrm{bp}$ long sequence of the cytochrome $b$ region provided a basic insight into the phylogenetic relationships of the genus Pseudopodisma. The phylogenetic tree, which was rooted on Ognevia, placed the genus in a strong- 
ly supported monophyletic clade with three main branches: (i) leading to the single sample of $P$. fieberi from Croatia, (ii) including two Romanian samples of $P$. transilvanica, and (iii) three samples of $P$. nagyi from Hungary. Within the latter clade it has identified a weakly supported sister relationship of the samples coming from the Aggtelek Karst and Zemplén Mts. The sample of the closely related species Odontopodisma rubripes was placed sister to the samples of Pseudopodisma.

\section{DISCUSSION}

We examined the morphological and molecular differentiation between three closely related putative species within the genus Pseudopodisma. While our sampling included specimens from the close vicinity of type localities in case of $P$. nagyi and P. transilvanica (Fig. 1), we could not include Slovenian specimen (i.e., from the type locality) of $P$. fieberi. This leaves us with some uncertainty regarding our taxonomic conclusions, although we believe we correctly extrapolated our a priori identification based on male genitalia.

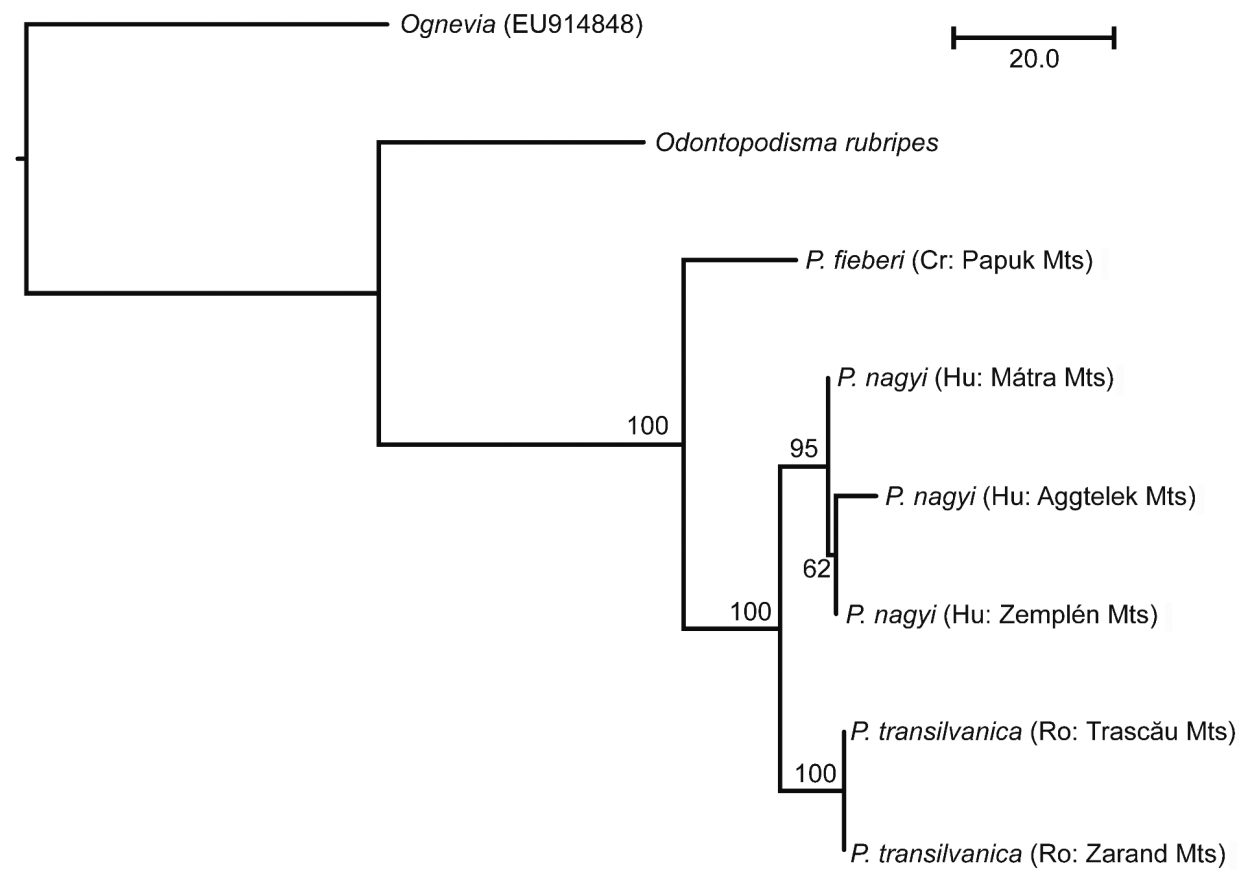

Fig. 4. The single most parsimonious phylogenetic tree for the genus Pseudopodisma obtained from an exhaustive search under maximum parsimony criterion and presented as a phylogram. Numbers above branches are bootstrap values resulting from 1000 pseudoreplicate. The scale bar represents 20 mutational changes 
The morphometric analysis indicated (i) sternum length (SL), (ii) sternum width (SW), and (iii) the lateral side width of pronotum (PLW) as the best discriminating morphological characters to distinguish males of $P$. nagyi from $P$. transilvanica and $P$. fieberi. This discrimination was statistically significant but the characters could only be used jointly (i.e., not separately) to discriminate the species. Nevertheless, when using the values of the three most significant morphometric characters in a multivariate approach, the separation of $P$. nagyi from the other two species was highly significant on the first discriminant axis. There was a very little separation between the other two species, $P$. transilvanica and $P$. fieberi, both in terms of statistical significance and actual measurements.

The most important morphometric characters for the females were (i) the width of third femur (TFW), (ii) the lateral side width of pronotum (PLW), (iii) the lateral side length of pronotum (PLL), and (iv) the length of tegmen (WL). In this gender, $P$. transilvanica was distinguished from the other two species along the first axis, however, P. nagyi was not separable from P. fieberi. P. transilvanica was statistically distinguishable from $P$. fieberi and $P$. nagyi, and the statistical difference between $P$. fieberi and $P$. nagyi was again very small along the second axis.

It is worth noting the morphometric results concerning the Zarand Mts. population in our study, which was identified based on male genital organs as $P$. transilvanica. One specimen from this population was somehow close to $P$. nagyi in morphology (Table 1), while the rest was classified according to the $a$ priori identification. The false classification of a single specimen from Zarand Mts makes the finding of Hoffmann (2008) - if that is made based solely on overall morphology and not genital structure - doubtful. Unfortunately, it is not clear from that paper if the author used genital characters to distinguish between the Pseudopodisma species, or the identification was based only on the descriptions of the cited literature.

In summary, individual morphometric characters were not suitable for the differentiation of the species contrary to the fact that we identified different degrees of morphological differences among the examined taxa. Nevertheless, combination of morphological characters in a morphometric analysis were able to distinguish male $P$. nagyi from the other congeners, whereas other characters made it possible to separate female $P$. transilvanica from the congeners. Male genital morphology was found to be supportive of the a priori identification within the genus Pseudopodisma, since the specimens examined were correctly classified into the a priori species with a success rate of $80-90 \%$ that we consider generally acceptable. These results gave us the confidence in concluding that the a priori taxa are morphologically subtly but significantly different, a finding what one would expect in case of slightly diverged species. 
The molecular dataset was somewhat sparing but provided very robust results with negligible homoplasy. The phylogenetic analysis based on mitochondrial DNA sequences has indicated the cohesive nature of the genus Pseudopodisma. More samples are needed from Podismini, especially genera Podisma (Berthold, 1827), Micropodisma (Dovnar-Zapolskij, 1932), etc., to test monophyly of the genus. Within the genus, we found three, highly supported (all have bootstrap support of $100 \%$ ) monophyletic clades, which corresponded to the a priori specific identification (i.e., P. fieberi, P. nagyi, P. transilvanica). The difference between the Mátra Mts sample and the reminders of $P$. nagyi is remarkable and, although only weakly supported, warrants further investigation. This result may indicate some phylogeographic structure within the dataset as the Mátra Mts is the highest mountain range in Hungary and geographically more isolated than Zemplén Mts or Bükk Mts. The preservation of this population therefore needs more attention. Altogether, we consider the phylogenetic results as supportive of the a priori species delimitation of GALVagni and Fontana $(1993,1996)$ within the genus Pseudopodisma.

It is notable however, that the molecular genetic data suggest a closer relationship of $P$. nagyi and $P$. transilvanica, whereas the morphometric results depict a somehow different pattern: in the morphometric space (Fig. 3) $P$. fieberi is impossible to distinguish from the congeners. This result might be explained by the different nature of the markers used; if any of the morphometric characters are under selection, the morphometric results can deviate from what we would expect if they were evolving neutrally-an advantage of the usage of (nearly) neutrally evolving molecular markers (НевERT et al. 2003). Secondly, if $P$. fieberi represents the earliest diverging lineage within the genus, we might expect less morphological divergence from more derived congeners.

Taking together the genital morphological, morphometric and genetic results, these data points towards a distinction at the species level among the three members within the genus Pseudopodisma. It must be, however, admitted that a denser sampling of the genus (i.e., phylogeographic survey) should be the next step in the work with this taxon, where only basic taxonomic work has been done before. Indeed, we cannot fully exclude the possibility that this genetic pattern is simply reflecting geographic variation (i.e., phylogeographic pattern), although we think the strong power of male genital organs and $\mathrm{C} y \mathrm{tB}$ sequences to characterize the species are suggestive of more profound isolation.

Our finding of some phylogeographic structure within our phylogenetic dataset can be the starting point of a more detailed molecular work in the genus, for which we provide here a useful molecular tool. Beyond the specific question, our results indicate that simple external morphometric techniques 
alone are not enough to clearly separate these grasshopper species from each other. We should combine these methods with genital morphometry and/or molecular genetic investigation. A more straightforward approach is however the combination of genital morphometry together with molecular genetic analysis, which can be highly useful in orthopteran taxonomy, especially in non-stridulating groups like Pseudopodisma.

Acknowledgements - We wish to thank Gergely Szövényi, Gellért Puskás and Zoltán Varga for sampling of specimens, Barnabás Nagy and János P. Tóth for helpful comments, the Aggtelek and the Bükk National Park Directorates for collection permits. The financial support of Kirill M. Orci is greatly acknowledged. The first author was supported by Pro Regione Foundation. The work of GS was supported by the grant no. TÁMOP 4.2.4.A/211-1-2012-0001 in frame of the "National Excellence Program" of Hungary co-funded by the European Social Fund. This work was supported by the János Bolyai Scholarship (BO/00001/15) of the Hungarian Academy of Sciences.

\section{REFERENCES}

Berthold, A. A. (1827): Latreille's natürliche Familien der Thierreichs aus dem Französischen mit Anmerkungen und Zusätzen von Dr. Arnold Adoph Berthold. - Landes-Industrie Comptoir, Weimar, $411 \mathrm{pp}$.

CorrêA, A. S., de Oliveira, L. O., Braga, L. S. \& Guedes, R. N. (2013): Distribution of the related weevil species Sitophilus oryzae and S. zeamais in Brazil. - Insect Science 20(6): 763-770. https://doi.org/10.1111/j.1744-7917.2012.01559.x

DovnaR-ZapolskiJ, D. P. (1932): Zur Kenntnis der palearktischen Podismini (Orthoptera, Acridoidea). - Trudy Zoologicheskogo Instituta, Akademii Nauk SSSR, Leningrad 1(3-4): 262-265. [in Russian with German summary]

Everitt, B. S. \& Dunn, G. (2001): Applied multivariate data analysis. 2nd ed. - Wiley, 344 pp. https://doi.org/10.1002/9781118887486

Fisher, R. A. (1936): The use of multiple measurements in taxonomic problems. - Annals of Eugenics 7: 179-188. https://doi.org/10.1111/j.1469-1809.1936.tb02137.x

Galvagni, A. \& Fontana, P. (1991): Pseudopodisma disconzii sp. n. delle prealpi venete (Italia Nord Orientale). - Atti della Accademia Roveretana degli Agiati 30: 31-36.

Galvagni, A. \& Fontana, P. (1993): Le specie del genere Pseudopodisma Mistshenko, 1947. - Atti della Accademia Roveretana degli Agiati 7B: 165-186.

Galvagni, A. \& Fontana, P. (1996): Descriziona della Pseudopodisma nagyi specie nuova dell' Ungheria Nord-Orientale. - Atti della Accademia Roveretana degli Agiati 7B(5B): 209-232.

Gilbert, M. T. P., Moore, W., Melchior, L. \& Worobey, M. (2007): DNA extraction from dry museum beetles without conferring external morphological damage. - PLoS ONE 2: e272. https://doi.org/10.1371/journal.pone.0000272

HALL, T. A. (1999): BioEdit: a user-friendly biological sequence alignment editor and analysis program for Windows 95/98/NT. - Nucleic Acids Symposium Series 41: 95-98. 
Harz, K. (1957): Die Geradflügler Mitteleuropas. - VEB Gustav Fischer Verlag, Jena, 494 pp. https://doi.org/10.1002/mmnd.4820170112

Harz, K. (1975): Die Orthopteren Europas / The Orthoptera of Europe. Vol. 2. - Dr. W. Junk B. V., The Hague, 939 pp. https://doi.org/10.1007/978-94-010-1947-7

Hebert, P. D. N., Crwinska, A., Ball, S. L. \& deWAard, J. R. (2003): Biological identifications through DNA barcodes. - Proceedings of the Royal Society of London, Series B: Biological Sciences 270: 313-321. https://doi.org/10.1098/rspb.2002.2218

НоскіNG, R. R. (1976): The analysis and selection of variables in linear regression. - Biometrics 32:1-49. https://doi.org/10.2307/2529336

Hofmmann, R. (2009): Zur Orthopterenfauna (Blattaria, Dermaptera, Mantodea, Ensifera, Caelifera) des westlichen Zarandgebirges (Rumänien). - Articulata 24(1-2): 109-121.

Holuša, J., KočÁrek, P., VlK, R. \& Marhoul, P. (2013): Annotated checklist of the grasshoppers and crickets (Orthoptera) of the Czech Republic. - Zootaxa 3616(5): 437-460. https://doi.org/10.11646/zootaxa.3616.5.2

Ilango, K. (2011): Radiation of the Oriental phlebotomine sand flies (Diptera: Psychodidae). - Insect Science 18(5): 590-606. https://doi.org/10.1111/j.1744-7917.2010.01378.x

Iorgu, I., Pisıcă, E., PĂış, L., Lupu, G. \& Iuşan, C. (2008): Checklist of Romanian Orthoptera (Insecta) and their distribution by eco-regions. - Travaux du Muséum National d'Historie Naturelle "Grigore Antipa" 51: 119-135.

KIs, B. (1961): Adalékok a Cozia-hegység Orthoptera faunájának ismeretéhez [Contributions to the knowledge of the Orthoptera fauna of the Cozia Mountains]. - Folia entomologica hungarica 14(28): 423-432.

KočÁrek, P., Holuša, J. \& VidlčıkA, L. (1999): Check-list of Blattaria, Mantodea, Orthoptera and Dermaptera of the Czech and Slovak Republics. - Articulata 14(2): 177-184.

KočÁReK, P., HolušA, J. \& VidLčıKA, L. (2005): Blattaria, Mantodea, Orthoptera \& Dermaptera of the Czech and Slovak Republics. - Kabourek, Zlín, 348 pp.

Litzenberger, G. \& ChAPco, W. (2001): Molecular phylogeny of selected Eurasian Podismine grasshoppers (Orthoptera: Acrididae). - Annals of the Entomological Society of America 94(4): 505-511. https://doi.org/10.1603/0013-8746(2001)094[0505:MPOSEP]2.0.CO;2

López, H., Contreras-Díaz, H. G., Oromí, P. \& Juan, C. (2007): Delimiting species boundaries for endangered Canary Island grasshoppers based on DNA sequence data. Conservation Genetics 8(3): 587-598. https://doi.org/10.1007/s10592-006-9199-5

Mardia, K. V., Kent, J. T. \& Bibby, J. M. (1979): Multivariate analysis. - Academic Press New York, London, 521 pp. https://doi.org/10.1002/bimj.4710240520

Mistshenko, L. L. (1947): Two new genera of the tribe Podismini (Orthoptera, Acrididae) from the Old World. - Proceedings of the Royal Entomological Society of London (B) 16: 10-12. https://doi.org/10.1111/j.1365-3113.1947.tb00839.x

Mutaten, M. \& Pretorius, E. (2007): Subjective visual evaluation vs. traditional and geometric morphometrics in species delimitation: a comparison of moth genitalia. - Systematic Entomology 32: 371-386. https://doi.org/10.1111/j.1365-3113.2006.00372.x

NAGY, A., RÁcz, I. A. \& VArgA, Z. (2005): Maculinea habitats in Hungary: Orthoptera assemblages. - Pensoft Series Faunistica 53: 16-21.

NAGY, A. \& RÁcz, I. A. (2007): Az Orthoptera fauna védelmének prioritásai az Aggteleki Nemzeti Parkban [Setting priorities for conservation of the Orthoptera species in the Aggtelek National Park (northeast Hungary)]. - Állattani Közlemények 92(1): 53-65. [in Hungarian]

NAgY, A., Orci, K. M., Rácz, I. A. \& VARgA, Z. (2007): Hazai gyeptípusok egyenesszárnyúi [Orthopterans of the Hungarian grasslands]. Pp. 349-356. In: Forró, L. (ed.): A Kár- 
pát-medence állatvilágának kialakulása [The evolution of the Carpathian Basin fauna]. Magyar Természettudományi Múzeum, Budapest. [in Hungarian]

Nagy, A., Kisfali, M., Szövényi, G., Puskás, G. \& RácZ, I. A. (2010): Distribution of Catantopinae species (Orthoptera: Acrididae) in Hungary. - Articulata 25(2): 221-237.

Orci, K. M., SzövéNyI, G. \& NAGY, B. (2010): Isophya sicula sp. n. (Orthoptera: Tettigonioidea), a new, morphologically cryptic bush-cricket species from the Eastern Carpathians (Romania) recognized from its peculiar male calling song. - Zootaxa 2627: $57-68$.

R Development Core Team (2009): R: A language and environment for statistical computing. R Foundation for Statistical Computing, Vienna, Austria. Available from www.rproject.org (accessed 10 September 2014).

Scudder, S. H. (1897): Revision of the orthopteran group Melanopli (Acridiidae), with special reference to North American forms. - Proceedings of the United States National Museum 20(1124): 112-115. https://doi.org/10.5479/si.00963801.20-1124.1

Simmons, R. B. \& Weller, S. J. (2001): Utility and evolution of cytochrome b in insects. - Molecular Phylogenetics and Evolution 20: 196-210. https://doi.org/10.1006/mpev.2001.0958

Swofford, D. L. (2003): PAUP*. Phylogenetic Analysis Using Parsimony (*and Other Methods). Version 4. - Sinauer Associates, Sunderland, Massachusetts.

TóтH, J. P. \& VARGA, Z. (2012): Inter- and intraspecific variation in the genitalia of the 'Melitaea phoebe group' (Lepidoptera, Nymphalidae). - Zoologischer Anzeiger 250: 258268. https://doi.org/10.1016/j.jcz.2011.05.002

Venables, W. N. \& Ripley, B. D. (2002): Modern applied statistics with S. 4th ed. - Springer, New York, 495 pp. https://doi.org/10.1007/978-0-387-21706-2

Weins, C., Ligges, U., LuebKe, K. \& RAAbe, N. (2005): klaR analyzing German business cycles. Pp. 335-343. In: Baier, D., Decker, R. \& Schmidt-Thieme, L. (eds): Data analysis and decision support. - Springer-Verlag, Berlin. https://doi.org/10.1007/3-540-28397-8_36

Received July 13, 2015, accepted January 11, 2017, published July 21, 2017 